\title{
Kelambanan Reformasi Birokrasi dan Pola Komunikasi Lembaga Pemerintah
}

\author{
Oleh: Eko Harry Susanto ${ }^{1}$
}

\begin{abstract}
When Indonesia entering the political reform, in the 1998, there's a strong demand for government to give a better public service. One reason that can support that hope is a bureaucracy reform. But the power shift in the reform era cannot give a good public service as people needed. The most reason is that the communication behavior of the leader in that political situation, trapped in the top down shape. In the mechanic society pattern is difficult to develop a good public services.
\end{abstract}

Key words: bureaucracy reform, leadership, communication pattern

\section{Pendahuluan}

Reformasi birokrasi menjadi jargon klise dalam pemerintahan pasca reformasi. Sejak pemerintahan B.J. Habibie sampai dengan kekuasaan Presiden Susilo Bambang Yudhoyono pada periode ke dua, sepertinya masih jauh dari harapan dan belum menampakkan hasil maksimal. Ini bisa dilihat dari berbagai masalah pelayanan kepada publik yang tersendat dan berbelit - belit.

Untuk mendukung keberhasilan reformasi birokrasi, diperlukan kepemimpinan birokrasi yang mampu menangani program pemerintah lebih baik. Sebuah pernyataan yang tidak mudah untuk dijalankan oleh organ - organ kekuasaan negara yang berniat untuk menciptakan good governance

Kepemimpinan birokrasi atau lebih tepat kepemimpinan dalam institusi pemerintah, seharusnya menjadi perhatian utama institusi negara pasca reformasi. Sebab model kepemimpinan birokrasi di Indonesia, yang dilembagakan seringkali mengarah upaya membangun jaringan komunikasi kekuatan aparatur pemerintah, untuk menguasai rakyat

1 Dosen Ilmu Komunikasi Universitas Tarumanagara 
secara sosial, ekonomi maupun politik. Akibatnya reformasi birokrasipun ibarat jalan ditempat tidak beranjak maju dan membaik dalam pelayanan kepada publik.

Sejatinya perilaku politisasi birokrasi semacam itu harus segera dihentikan. Namun persoalannya, meskipun reformasi telah bergulir lebih dari satu dasawarsa, tetapi jerat historis karakteristik dan model komunikasi di lingkungan birokrasi pemerintah belum pudar. Sejumlah institusi negara masih terperangkap dalam pelembagaan kekuatan aparatur pemerintahan , demi untuk menghadapi masyarakat pada umumnya.

Tidak bisa dipungkiri, bahwa komunikasi yang mengunggulkan kekuasaan masih menonjol di lembaga - lembaga sub ordinat kekuatan pemerintah. Sebagai kelas dominan berkuasa, komunikasi yang seringkali muncul adalah mempertahankan eksistensi model komunikasi otoritarianisme roda. Elite di lembaga pemerintah merupakan poros yang memproduksi informasi, dengan menitikberatkan kepada pesan "tidak bisa tidak" harus diterima, meskipun merugikan masyarakat. Memang, dalam berbagi retorika di hadapan publik, aparat lazim mengunggulkan demokratisasi dan kesetaraan dalam interaksi dan komunikasi.

Melalui komunikasi yang bersifat memaksa dan dikemas dalam bingkai formalistik, maka hubungan antara birokrasi pemerintahan dengan masyarakat lebih banyak diwarnai oleh perbedaan kepentingan yang berdampak pada tidak adanya pembentukan makna bersama yang disepakati dua belah pihak. Di sisi lain, yang menonjol adalah terciptanya jarak kekuasaan kronis dalam relasi antara antara pemerintah sebagai pemegang kebijakan, dengan masyarakat dalam posisi sebagai penerima pesan belaka.

Mencermati kondisi tersebut, dan berpijak kepada demokratisasi dalam komunikasi maupun niat untuk memberikan pelayanan kepada publik yang lebih baik, maka reformasi birokrasi harus didukung oleh para pemimpin organisasi pemerintah yang mampu menciptakan komunikasi integratif dengan masyarakat sebagai entitas yang wajib dilayani.

\section{Birokrasi dan Karakteristik Masyarakat}

Secara umum, model birokrasi sering dianologikan sebagai kultur feodalisme dalam pemerintahan di Indonesia. Didalamnya mengandung hak komunikasi yang lebih ditekankan kepada hak komunikasi para pemilik kekuasaan dalam struktur - struktur pemerintahan. Padahal, sebenarnya birokrasi adalah model ideal untuk mencapai tujuan organisasi 
yang juga mengunggulkan peranserta berbagai pihak dalam struktur untuk bekerja sesuai dengan kapasitas dan tanggungjawabnya.

Dalam tinjuan historis, kapitalisme di Amerika Serikat berkembang karena dukungan birokrasi dalam tipe ideal (Timasheff, Nicholas, 1967; Weber, 2002). Bukan penyimpangan dari birokrasi yang sering kita dengar dengan istilah "birokratis". Kemajuan birokratisasi di dalam dunia modern secara langsung bertalian dengan perluasan pembagian kerja di semua bidang kehidupan sosial (Max Weber dalam Gidden, 1986 : 195), yang secara konsisten dilakukan oleh negara demokratis dengan pelayanan publik yang memadai. Beberapa proposisi yang terkait dengan birokrasi anatara lain adalah : Birokratisasi bertalian dengan perluasan pembagian kerja di semua bidang kehidupan sosial untuk mencapai kesejahteraan (Giddens, 1986). Ciri - ciri birokrasi menurut Max Weber adalah (a) adanya pembagian kerja, (b) adanya hirarki (c) memiliki aturan dan prosedur (d) kualifikasi profesional dalam pelaksanaan pekerjaan (e) hubungan dalam organisasi bersifat tidak pribadi / impersonal. (Myers dan Myers, $1988: 21$ ).

Sementara itu, fungsi birokrasi menurut Weber (dalam Giddens, 1986), secara substantif mencakup : (a) Spesialisasi yang memungkinkan produktivitas, (b) Struktur yang memberikan bentuk pada organisasi (c) Predictability (keadaan yang dapat diramalkan ) dan stabilitas yang dapat dikerjakan (d) Rasionalitas yang dapat diuji dan diunggulkan dalam tindakan menciptakan sinergi untuk memaksimalkan keuntungan.

Kendati birokrasi memiliki keunggulan dalam menjalankan roda organisasi, tetapi tidak bebas dari kelemahan yang faktual. Kritik Warren Bennis (dalam Myers and Myers, 1988: 31) terhadap birokrasi, pada intinya adalah, walaupun birokrasi selalu dikaitkan dengan keteraturan dalam penyelenggaraan organisasi, tetapi tidak sepenuhnya bisa membuat efektivitas birokrasi. Beberapa faktor yang menghambat, anatara lain, birokrasi tidak cukup memberikan peluang untuk pertumbuhan pribadi dan pengembangan kepribadian yang matang karena terlalu banyak prosedur dan kekakuan struktur. Lebih banyak mengembangkan kompromi (conformity) dan pemikiran kelompok dengan berbagai macam keharusan yang sulit untuk dilakukan.

Dalam dinamika perubahan, birokrasi seringkali tidak mampu memperhitungkan organisasi informal dan masalah yang timbul tidak terduga dalam pelaksanaan kegiatan. Dengan kata lain, birokrasi bersifat sangat konvensional tidak mampu mengantisipasi perubahan. Karena itu, 
pola komunikasi dalam institusi pemerintah yang bersifat top - down, juga tetap berjalan tanpa hambatan berarti.

Birokrasi juga sering dikaitkan dengan, sistem pengawasan dan wewenangnya sangat ketinggalan jaman. Ini dapat terjadi karena pola penyimpangan berjalan sesuai dengan perkembangan ilmu dan teknologi, di lain pihak birokrasi menetapkan prosedur pengawasan selalu membutuhkan waktu yang sangat panjang. Selain itu menurut Bennis (Myers dan Myers, 1988:34), birokrasi tidak mempunyai proses peradilan, dalam arti birokrasi hanya mampu memberikan sanksi administratif terhadap penyimpangan dan penyalahgunaan kekuasaan, tidak memiliki alat - alat yang cukup untuk menyelesaikan perbedaan - perbedaan dan konflik - konflik antara berbagai tingkatan (rank). Pola penyelesaian yang merujuk pada pedoman sentral yang seragam sering tidak mampu untuk menyelesaikan konflik dengan baik.

Dalam kaitannya dengan komunikasi, karena struktur hirarki yang kuat, maka komunikasi dan ide - ide pembaharuan terhalang atau tersimpang karena pembagian pelapisan kekuasaan yang kuat. Bahkan ide yang berhasil sampai kepermukaan serta dipakai dalam organisasi sering diklaim sebagai kesuksesan pimpinannya yang sama sekali tidak terkait oleh dukungan bawahan.

Kelemahan lain dalam birokrasi adalah, sumber daya manusia tidak dimanfaatkan sepenuhnya karena kecurigaan, ketakutan akan pembalasan, tersaing dsb; yang disokong adalah perilaku cari selamat. Selain itu, aspek faktual dalam penggunaan teknologi, birokrasi tidak dapat membaurkan teknologi baru, dalam konteks ini bisa teknologi komunikasi, dengan pekerjaan yang dihadapi. Kalaupun mengadopsi teknologi, diperlukan perundingan yang sangat bertele - tele dan persetujuan tetap didasarkan pada struktur organiasasi, tanpa menghiraukan kebutuhan yang mendesak.

Birokrasi dapat merubah struktur kepribadian sedemikian rupa sehingga manusia dalam organisasi menjadi orang yang menjemukan dan kelabu. Pola komunikasi yang dijalankan tidak variatif dan cenderung linier kurang variatif. Karyawan harus tunduk terhadap bermacam macam aturan organisasi yang kaku dan bersifat serba wajib. Akibat lebih jauh interaksinya dan pelayanan kepada publik kurang menarik, bersifat monoton, mudah melakukan tindakan represif dan sering merasa selalu benar dan gerak kemajuan sesungguhnya mirip siklus yang tidak pernah maju secara progresif. 
Tatanan birokrasi memang selalu merujuk pada faktor yang ideal dalam menjalankan organisasi termasuk sebagai acuan untuk menyelenggarakan pemerintahan dengan baik. (Etzioni, 1997: 53). Namun persolannya, karakter birokrasi tidak lepas dari sifat masyarakat yang paternalistik terikat oleh nilai kolektivitas. Akibatnya, sistem kerja organik sebagaimana ditetapkan oleh birokrasi menjadi sulit untuk diterapkan.

Mentalitas dan budaya paternalistik menurut Hamijoyo (2003), "lebih banyak berorientasi kepada atasan atau penguasa, sehingga menghambat munculnya sikap mandiri, inovatif dan kreatif". Komunikasi yang dibentukpun ditujukan ke pimpinan dibandingkan kepada masyarakat yang harus dilayani. Dalam jerat paternalistik, masyarakat masyarakat belajar dari kehidupan sehari - hari bagaimana sang pemimpin atau atasan benar - benar menikmati kedudukan dan peranannya, sehingga lama - lama orang secara sadar atau tidak sadar menokohkan atasannya.

Dalam pandangan Rogers dan Svenning (1967: 219), kepemimpian paternalistik di negara sedang berkembang didominasi oleh simbol simbol keberhasilan sepihak yang mengabaikan tanggungjawab kepada masyarakat yang umumnya yang mengungulkan pemilik kekuasaan. Sementara itu, menurut Hannah Arent (dalam Sudibyo,2009 : 197), birokrasi sebagai kekuasaan no-body dalam prakteknya mengarah pada kekuasaan despotik dan tiranik juga. Dengan kata lain, kekuasaan yang selalu berlindung dibalik aspek legal birokrasi memang berpotensi memicu kepemimpimpinan otokratis yang tidak peduli kepada rakyat.

Jika dihubungkan dengan kultur organisasi patronage, birokrasi pemerintah dinilai kurang disiplin. Rasa takut dan taat hanya kalau ada atasannya yang mengawasi. Dengan kata lain, orientasinya hanya kepada orang - orang yang menduduki posisi diatasnya, bukan kepada prinsip atau aturan. Selain itu, tidak jarang kepentingan keluarga yang justru diterapkan untuk menyelesaikan suatu masalah dalam organisasi pemerintahan dibandingkan berpijak kepada aturan mendasar dalam menjalankan organisasi yang profesional sesuai prosedur yang ditetapkan. Padahal semestinya, dalam semangat reformasi birokrasi, kepentingan umum harus dikedepankan.

\section{Kepemimpinan Birokrasi dan Eksistensi Komunikasi}

Melihat kondisi birokrasi pemerintahan dan karakteristik masyarakat yang mempengaruhi perilaku birokrasi, maka tidak aneh 
jika reformasi birokrasi berjalan lambat. Karateristik masyarakat yang melekat dalam birokrasi mengakibatkan pola komunikasi yang dibangun juga tidak demokratis, lebih berpihak kepada para elite dalam kekuasaan negara. Samovar, Porter dan Mc.Daniel (2007:369), " karakteristik budaya mempengaruhi pola komunikasi seseorang dalam interaksi, dan ini akan semakin nampak ketika berhubungan dengan orang dari budaya atau kelompok yang berbeda. Pada konteks ini, birokrat dengan budaya kelas dominannya dan masyarakat dengan berbagai kewajibannyan untuk tunduk kepda kekuatan negara. Dua pihak itu memiliki diferensiasi yang menyulitkan dalam menjalankan reformasi birokrasi di lembaga pemerintah.

Mengutip pendapat F. Budi Hardiman (2010:13), ” pihak yang kuat itu birokrat, investor, boleh bicara 'bahasa hak-hak' dan memiliki semua hak yang mereka perlukan untuk hidup, sementara yang lemah dianggap tidak pantas untuk memiliki atau mengklaim haknya". Dengan kondisi semacam itu, sulit bagi birokrasi pemerintahan untuk memberikan pelayanan kepada publik yang lebih baik sebagaimana harapan masyarakat. Pelayanan publik, lazimnya menyangkut pelayanan identitas, kesehatan, pendidikan , ekonomi, dokumen hukum menyangkut hak milik atau hak ekonomi. Bisa dibilang pelayanan publik adalah semua dokumen yang menyangkut hak milik dan hak ekonomi (Farouk Arnaz dkk, 2009 : 55).

Jika pelayanan kepada publik tidak kunjung membaik, maka reformasi birokrasi yang juga mengusung good governance sulit diwujudkan. Dalam kajian United Nation Development Program (UNDP), good governance adalah suatu kesepakatan menyangkut pengaturan negara yang diciptakan bersama oleh pemerintah, masyarakat madani dan sektor swasta demi terwujudnya kesejahteraan sosial. (Emil A. Lagut, 2009: 17). Terkait dengan masyarakat madani, menurut Supeli (dalam Hamid dkk : 2010: 19), jantung civil society adalah civility - keberadaban. Antitesis dari civility adalah kekerasan dan ketidakberadaban. Munculnya ketidakberadaban karena ketiadaan polity (tatanegara). Sebagai warganegara, seseorang bertindak atas dasar konstitusi . Tanpa polity, tanpa konstitusi, yang berlaku adalah hukum rimba.

Upaya meningkatkan pelayanan kepada publik dan menciptakan kekuatan masyarakat madani, diperlukan kepemimpinan birokrasi yang mampu mampu berinteraksi dan berkomunikasi dengan seluruh lapisan masyarakat. Kepemimpinan dalam perspektif komunikasi adalah suatu kegiatan komunikasi untuk mempengaruhi orang-orang supaya dapat bekerjasama dalam mencapai tujuan yang diinginkan. Sejalan dengan 
itu, Haiman (dalam Bass, 1974:7) menyatakan, "kepemimpinan adalah kemampuan mempengaruhi dalam proses interaksi melalui pembicaran ataupun melalui prilaku orang lain".

Sedangkan menurut Keith Davis (1972 :96), “ kepimimpinan merupakan kemampuan untuk mempengaruhi orang lain melalui komunikasi dan aktivitas lainnya secara bersemangat dalam rangka mencapai tujuan yang telah ditentukan". Sedangkan Rogers dan Svenning (1969 :223) , menegaskan, “ kepemimpinan merupakan kemampuan bertindak dan berkomunikasi untuk mempengaruhi orang lain sesuai dengan jalan yang diinginkan untuk mencapai tujuan yang telah ditetapkan".

Esensinya, unsur -unsur yang menonjol dalam kepemimpinan adalah, kemampuan berkomunikasi untuk mempengaruhi seseorang atau kelompok dengan cara yang tidak memaksakan kehendak. Tetapi kegiatan mempengaruhi sebagai satu hal yang tidak mudah dilakukan, karena berbagai macam kendala yang dipunyai pemimpin maupun pengikut. Sehingga pada pemimpin dalam lembaga pemerintah seringkali menggunakan aspek kekuasaan legal formal untuk memaksa agar masyarakat mengikuti apa kemaunannya.

Jika kepemimpinan birokrasi pemerintahan dilakukan dengan merujuk kepada pengertian ideal tentang kepemimpinan, maka hubungan antara pemerintah dengan rakyat dapat berjalan dengan baik, karena didalamnya tidak ada perilaku kursif dari aparat pemerintah. Paul Hersey dan Kenneth Blanchard (dalam Myers \& Myers,1998 :194-195), intinya menyatakan bahwa, pemimpin yang berhasil adalah mereka yang selain memiliki kemampuan pribadi tertentu, juga mampu membaca keadaan anak buah dan lingkungannya. Model ini bertitik tolak dari pendekatan situasional yang berpedoman pada tidak ada gaya kepemimpinan yang selalu efektif untuk diterapkan dalam setiap situasi, gaya kepemimpinan akan efektif jika disesuaikan dengan tingkat kematangan atau kemampuan anak buah.

Dalam perspektif komunikasi, menjalankan roda organisasi pemerintah harus mengunggulkan perilaku komunikasi yang integratif, demi untuk menghasilkan kesepakatan bersama dalam menyikapi kebijakan publik. Dikaitkan dengan tujuan, Littlejohn dan Foss (2009:185), menegaskan bahwa, banyak tujuan dapat dicapai dengan cara komunikasi a tertentu dan komunikasi sangat sentral dalam mencapai tujuan sosial.

Sedangkan Rogers (1986:209), mengatakan "komunikasi merupakan proses dimana mereka yang terlibat di dalamnya, menciptakan dan berbagi 
informasi satu dengan lainnya, untuk mencapai pengertian bersama”. Bukan penyampaian pesan dengan nuansa propaganda, yaitu upaya sistematis yang menggunakan simbol - simbol, untuk menggerakkan sikap dan tindakan orang lain demi untuk mencapai tujuan yang dikehendaki. (Anokwa, Lin dan Salwen, 2005: 17).

Persoalannya, dalam propaganda seringkali mengingkari fakta sosial yang ada dan cenderung memaksa. Dalam pandangan Oetomo (2009:77), ada otokrasi yang kebabalasan menjadi praktek represi serta praktik KKN, ternyata dan terbukti akhirnya menjadi kontraproduktif dan destruktif. Kendati demikian menurut Susanto (dalam Gillet et.al. 2010 : 157), biasanya elite dalam pemerintahan negara sedang berkembang tetap saja merasa sudah menjalankan demokrasi. Meskipun sesungguhnya jauh dari makna demokrasi universal yang menekankan kepada kebebasan berserikat, berkumpul, mengemukakan pendapat, mencari penghidupan yang layak dan sederetan nilai lain yang menghargai kebebasan maupun perbedaan

Prinsipnya, elite dalam struktur birokrasi harus mampu menciptakan komunikasi yang efektif, tanpa unsur memaksa dan menjunjung keberadaban dalam demokrasi komunikasi. Goyer (dalam Tubb dan Moss, 2006 : 24), komunikasi dinilai efektif, bila rangsangan yang disampaikan dan dimaksud oleh pengirimnya ataupun sumber pesan, sejalan dengan rangsangan yang ditangkap dan dipahami oleh penerima pesan. Lima faktor yang dapat dipakai sebagai ukuran untuk menetapkan komunikasi berjalan dengan efektif adalah (1) pemahaman terhadap pesan oleh penerima pesan, (2) memberikan kesenangan kepada pihak - pihak yang berkomunikasi seperti halnya dalam mempertahankan hubungan, (3) mampu mempengaruhi sikap orang lain, (4) memperbaiki hubungan, (5) memberikan hasil yang sesuai dengan yang diinginkan dalam bentuk tindakan dari penerima pesan.

Meskipun komunkikasi efektif dapat ditunjang oleh bebagai kesamaan karakter dari pihak - pihak yang berkomunikkasi, tetapi ada masalah - masalah yang berpotensi menjadi penghalang komunikasi efektif. Pada konteks ini, khususnya yang menyangkut aliran informasi dalam organisasi. Dalam pembahasan tentang perilaku organisasi yang dihubungkan dengan peran ataupun eksistensi komunikasi dalam organisasi, Stephen P. Robbins (2002 : 14) memaparkan beberapa faktor yang berpotensi menghambat tercapainya komunikasi, yaitu : (1) Penyaringan atau manipulasi terhadap informasi, dengan tujuan supaya 
menguntungkan atau merugikan bagi penerima informasi. (2) Persepsi Selektif, melihat, mendengar berdasarkan kebutuhan individual. Tindakan ini cenderung mengabaikan substansi pesan yang lebih luas, tetapi hanya menggarusbawahi pesan yang dibutuhkan. (3) Emosi atau perasaan penerima ketika menerima pesan. Jika penerima pesan dalam keadaan emosi, maka pengirim pesan sulit untuk memperoleh respon yang diharapkan, demikian juga sebaliknya jika pengirimb pesan masih diliputi rasa emosi, penerima pesanpun juga memberikan respon yang berbeda dengan maksud pesan yang sesungguhnya

Pada prinsipnya komunikasi yang efektif harus menciptakan kesamaan makna antara pengirim dan penerima pesan. Karena ada kesepakatan ataupun kesepahaman pihak yang melani dan dilayani, maka harapan masyarakat untuk memperoleh pelayan publik yang lebih baik bisa . Kepemimpinan dalam sistem demokrasi diperlukan kemampuan berkomunikasi, persuasi, kesabaran mengajak dan meyakinkan,ketahanan menjalani pebedaan, mendengarkan kritik, tetapi sebaliknya setiap kali harus mau dan mampu menemukan pengertian, saling pengertian, kesepakatan atau konsensus. ( Oetomo, 2009 : 88).

Menurut Samovar, Porter and McDaniel (2005: 365), komunikasi bersifat dinamis, simbolik, sistematik, kontekstual dan memiliki konsekuensi dalam hubungan antar manusia. Proses komunikasi juga menyangkut kerangka pemikiran pihak yang berkomunikasi, karakteristik pengirim, penerima, jenis pesan dan media yang digunakan, maka untuk menghasilkan komunikasi yang efektif tidak mudah. Bahkan dilingkungan masyarakat di akar rumput, menurut Susanto (2009: 45), komunikasi selalu menunjuk pada porsi kekuasaan yang lebih besar, dibandingkan hak rakyat untuk bicara dan mengungkapkan pendapatnya. Karena itu, tidak jarang bahwa retorika para pemilik kekuasaan akan mendominasi semua keputusan - keputusan yang dilakukan dalam pembangunan.

Namun dalam koridor reformasi politik yang bertadab, selayaknya jika birokrasi pemerintahan mengedepankan demokratisasi komunikasi yang memberikan hak bicara kepada semua lapisan masyarakat, sehingga tercipta hubungan kohesif, antara aparat pemerintahan dengan rakyat. Dengan demikian, reformasi birokrasi yang berusaha membenahi birokrasi di tubuh pemerintah dapat berjalan sesuai harapan dan berdampak kepada pelayanan kepada publik yang semakin baik. 


\section{Reformasi Birokrasi : Menjalankan Organisasi Dengan Ideal}

Reformasi birokrasi, sesungguhnya bukan suatu hal yang baru dalam dinamika organisasi. Sebab, dengan menjalankan birokrasi pemerintahan sesuai dengan substansi birokrasi, merupakan salah satu faktor yang sangat mendukung tercapainya pembenahan birokrasi di tubuh pemerintah. Namun yang menjadi persoalan adalah, karakter kepemimpinan birokrasi secara kelembagaan maupun personal yang mengedepankan pola komunikasi interaktif dan demokratis teramat langka walaupun jargon reformasi hampir setiap saat kita dengar. Karena itu, jika reformasi birokrasi sebagai penunjang demokrasi bernegara, maka reformasi birokrasi harus kembali ke ideal type model Max Weber, dengan meminimalisir berbagai kelemahan yang membelenggu dan terlembaga.

Dalam perspektif organisasional yang menekankan aspek sosial, kepemimpinan birokrasi berlindung dibalik peraturan dan tidak menempatkan rakyat dalam kesetaraan. Mengutip pendapat William J. Reddin, dari The 3-D Management Style Theory, "gaya kepemimpinan birokrasi pada umumnya memiliki orientasi tugas ringan, hubungan lemah, menaruh perhatian pada aturan ataupun prosedur demi kepentingan mereka sendiri, dan karena ingin menjaga serta mengawasi situasi dengan menggunanakan aturan serta prosedur, mereka sering terlihat amat berhati - hati". Jika model kepemimpinan birokrasi, dalam konotasi negatif tersebut dipertahankan, alangkah mengkhawatirkannya bagi upaya memperbaiki kinerja pemerintah dalam memberikan pelayanan kepada publik lebih baik.

Karena itu, reformasi aparatur di lembaga pemerintah, harus meminimalisir nilai-nilai negatifmasyarakat mekanistik dan menghasilkan aparat maupun pemimpin yang berpihak pada kepentingan publik. Mencari model kepemimpinan ideal dalam birokrasi pemerintah, harus kembali ke makna birokrasi Max Weber yang ideal. Karena itu, selayaknya jika ditekankan pada reformasi aparat dan lembaga pemerintah untuk mengikis belenggu birokratis sebagai bentuk penyimpangan pelaksanaan organisasi pemerintahan yang ideal.

Persoalannya, hingga lebih dari satu dasawarsa, yang masih menjadi penghalang reformasi birokrasiadalah karakteristikbirokrasi pemerintahan yang tetap saja merasa sebagai kelas dominan dalam masyarakat. Pandangan Agus Sudibyo, meskipun dalam konteks media, tetapi bisa dipakai sebagai rujukan bahwa birokrasi berjalan di tempat. Ditegaskan, meskipun zaman sudah berganti dan kondisi politik sudah jauh berubah, 
tidak demikian dengan cara pandang pemerintah terhadap media. Belum terjadi transformasi kultur yang membuat para pejabat pemerintah lebih apresiatif terhadap terhadap hak publik atas informasi dan kebebasan pers. Dalam tubuh birokrasi kita, belum terlahir pemahaman baru yang memadai tentang ruang publik yang otonom dari intervensi negara serta tentang fungsi - fungsi sosial media (Agus Sudibyo, 2010:46)

Sehaluan dengan itu, Supriatma (dalam Prisma, 2009:5), menyebutkan, " sekalipun Indonesia lepas ari jerat otoritarianisme, tetapi tidak lepas dari jerat oligarki yang memang sudah ditenun dalam struktur politik Indonesia sejak lama". Mencermati kondisi itu, tidak mudah mengubah birokrasi yang adaptif terhadap tuntutan reformasi birokrasi untuk memberikan pelayanan publik yang memadai. Untuk mengubah perilaku birokrasi diperlukan pemimpin yang memiliki pandangan progresif dalam menghadapi tantangan masa depan, memiliki perhatian tinggi terhadap upaya meningkatkan produktivitas kerja, peduli terhadap hubungan manusia dan mempunyai sejumlah karakteristik kepribadian lain yang positif. Nilai kepemimpinan semacam ini, diharapkan mampu memotivasi aparatur pemerintah untuk menciptakan good governance.

Persoalannya, birokrasi pemerintahan tidak bisa lepas dari jerat kekerabatan, kesamaan ideologis, kesamaan etnik serta relasi - relasi sosial ekonomi dan politik yang eksklusif. Dengan mentalitas berorientasi pada atasan, birokrasi potensial untuk menciptakan kesejahteraan semu (pseudo wellfare) melalui kalkulasi kuantifikasi yang sangat menonjol dalam mengunggulkan kebijakan publik. Tidak dapat disangkal bahwa, meningkatnya angka - angka dalam kebijakan pembangunan sosial, ekonomi dan politik sangat disukai oleh para pemegang otoritas kekuasaan negara. Keberhasilan menjalankan kebijakan publik melalui kultur kuantifikasi seringkali tidak berjalan linier dengan gambaran utuh kondisi masyarakat yang semakin terpinggirkan dalam perangkap kemiskinan.

Kebudayaan angka dalam menjalankan fungsi negara potensial menimbulkan sikap "arogansi keberhasilan" kinerja birokrasi, sebagaimana kebiasaan mengukur pendapatan per jiwa, yang kurang mengindahkan distribusi pendapatan ke seluruh wilayah ataupun kelompok masyarakat yang ada. Disisi lain kebudayaan mengangkakan keberhasilan dalam pelayanan publik, seringkali tidak dirasakan oleh masyarakat.

Kendati demikian harus diakui bahwa, reformasi birokrasi yang berjalan lamban bukan semata - mata kesalahan kepemimpinan di dalam 
lembaga pemerintah yang menjalankan organisasi tidak sesuai dengan hakikat birokrasi ideal. Sebab karakteristik statis dan lamban (indolent) masih mewarnai perilaku masyarakat yang kurang sadar mutu, terpikat pada apa yang sudah ada dan dianggap terbaik, mentalitas bekerja asal selesai dan asal ada hasilnya sangat menonjol, kurang terbuka, kurang mengenal pandangan alternatif dalam pengambilan keputusan dan menyukai kompromisme. Dengan kondisi semacam ini, masyarakatpun kurang peduli terhadap reformasi birokrasi. Telebih lagi, kepercayaan terhadap elite dalam kekuasaan negara maupun politik semakin pudar, ketika reformasi politik tidak kunjung membawa kesejahteraan.

Terlepas dari sejumlah asumsi diatas, tetapi secara faktual birokrasi masih tetap diunggulkan untuk menjalankan roda organisasi untuk mencapai tujuan. Dengan demikian, karakteristik patronage dan mentalitas statik selayak tidak selalu dijadikan kambing hitam untuk bersikap pesimis dan skeptis dalam mebenahi birokrasi pemerintahan. Sebab hakikatnya yang paling penting untuk dilakukan dalam reformasi birokrasi adalah memangkas karakteristik negatif dalam birokrasi, dengan menjunjung tinggi demokratisasi komunikasi demi kesejahteraan rakyat.

\section{Penutup}

Reformasi birokrasi masih menghadapi berbagai hambatan yang bersifat internal dalam tubuh birokrasi pemerintahan yang masih melembagakan pola komunikasi paternalistik dan faktor eksternal yang dikaitkan dengan sikap masyarakat yang statik, pesimis dan skeptis terhadap upaya pembenahan pelayanan kepada publik. Kalaupun sekelompok masyarakat bisa menikmati pelayanan publik lebih baik dibanding dengan yang lain, biasanya bergantung kepada kekuatan sosial, ekonomi dan politik kelompok di masyarakat yang bisa mempengaruhi kekuasaan negara. Namun komunitas ini amat terbatas, sehingga pelayanan publik pada umumnya masih jauh dari memadai.

Karena itu yang diperlukan dalam reformasi birokrasi adalah, memangkas karakteristik negatif dalam birokrasi pemerintahan dan memberikan penguatan kepada masyarakat agar memahami hak atas pelayanan publik. Melalui kebebasan komunikasi dan demokrasi dalam pelaksanaan program pemerintah, reformasi birokrasi dapat berjalan dengan baik sesuai harapan masyarakat.

Pada hakikatnya jika birokrasi dalam lembaga pemerintah masih 
mempertahankan pola paternalistik ketika berinteraksi dan berkomunikasi dengan masyarakat, maka reformasi birokrasi tidak akan mencapai hasil yang maksimal. Pelayanan kepada publik yang lebih baik tidak akan terwujud, dan upaya untuk mewujudkan good governance hanya sebatas retorika sebagai pemantas tuntutan rakyat

\section{Daftar Pustaka}

Anokwa, Kwadwo, Carolyn A. Lin and Michael B. Salwen.2003. International Communication : Concepts and Cases, Wadsworth Publishing

Arnaz, Farouk dkk (ed).2009. Api Yang Tak Pernah Padam : Catatan Konggres Pejuang HAM 2009, Jakarta : Penerbit CV. Rinam Antartika dan KontraS.

Asasi.2007. Analisis Dokumentasi Hak Asasi Manusia. " Politik Untuk Kebaikan Bersama. - Daniel Hutagalung. Edisi Desember 2007, Jakarta : Penerbit ELSAM

Asasi.2009. Analisis Dokumentasi Hak Asasi Manusia. "Membenahi Paradoks Otonomi Daerah dan Meredupnya Semangat Good Governance - Emil A. Laggut. Jakarta : Penerbit ELSAM

Bass, Bernard M.1976. Stogdill's Handbook of Leadership, A Survey of Theory And Research, The Free Press, New York 1981Chirot, Daniel.1976, Social Change in Twentieth Century, New York : Academy Press

Davis, Keith.1972. Human Relations At Work, Mc.Graw Hill Book Co, Inc, Kogakusha Co Ltd, Tokyo

Durkheim, Emile. 2002. www. scripps.ohiou.edu / file. Sociology.

Etzioni, Amitai, (1985),Organisai- Organisasi Modern, Jakarta : Penerbit Universitas Indonesia Press.

Giddens, Anthony . 1986. Capitalism and Social Modern Theory : An Analysis of Writing of Mark, Durkheim and Max Weber, atau Kapitalisme dan Teori Sosial Klasik dan Modern : Suatu Karya Tulis Marx, Durkheim dan Max Weber, terjemahan Soeheba K., Jakarta: UI Press.

Gillet, Catherine, Douglas Obura, et.al.2010. Globalization : Social Cost and Benefits for the Third World. "Communication Technology and the Problems of Developing Countries" oleh Eko Harry Susanto. Surakarta : Penerbit UNS Press. 
Hamijoyo, Santoso S. 2003." Aplikasi Model Komunikasi Dari Perubahan Sikap Dalam Riset Pembangunan Masyarakat Pedesaan "PPS Universitas Padjadjaran

Kontras. 2010. Duabelas Tahun KontraS, “ Human Loves Human : Politik Kewargaan : Sebuah Harapan Kemanusiaan Indonesia " oleh F. Budi Hardiman, Jakarta : Penerbit KontraS

Hoogvelt, Ankie M .1976. The Sociology of Developing Societes, The Mac Millan Press Ltd.

Hamid, Usman dkk. 2010. Menolak Kekerasan , Merawat Kebebasan : Sepuluh Tahun Pergulatan KontraS. "Menolak Kekerasan, Merawat Kebebasan" oleh Karlina Supeli, Jakarta : Penerbit KontraS

Koontz, Harold and Cyril O'Donnel, (1980), Management, London : Mc.Graw Hill Publishing

Littlejohn, Stephen W dan Karen A. Foss.2009. Teori Komunikasi terjemahan Theories of Human Communication oleh Mohammad Yusuf Hamdan, Jakarta : Penerbit Salemba Humanika.

Myers, Michele Tolela and Gail E. Myers .1988. Managing By Communication, New York, New Newsey, London, Mc. Graw Hill Int. Book. Co.

Oetoma, Jakob.2009. Bersyukur dan Menggugat Diri, Jakarta : Penerbit Kompas

Prisma.2009. Majalah Pemikiran Sosial Ekonomi. Edisi Juni 2009: Senjakala Kapitalisme dan Krisis Demokrasi "Requiem Dini, Krisis Finansial dan Krisis Demokrasi” oleh Yudi Latif. Jakarta : Penerbit LP3ES

.2009. Majalah Pemikiran Sosial Ekonomi. Edisi Oktober 2009\{ Menuju Indonesia Masa Depan. “Menguatnya Kartel Politik Para Boss" oleh Antonius Made Tony Supriatma, Jakarta : Penerbit LP3ES

Robbins, Stephen P (2002), Organizatioonal Behaviour, New Jersey : Prentice Hall Publishing Inc.

Rogers, Everett M and Lynne Svenning . 1969. Modernization Among Peasant, New York: Holt, Rinehart and Winston.

Rogers, Everett M.1986. Communication Technology : The New Media in Society, New York: The Free Press.

Samovar, Larry A and Richard E. Porter and Edwin R. McDaniel. 2005. Communication Between Cultures, Sixth Edition, Australia : 
thomson Wadsworth

Sudibyo, Agus.2010. Kebebasan Semu : Penjajahan Baru di Jagat Media, Jakarta : Penerbit Kompas.

Susanto, Eko Harry.2009. Komunikasi Politik dan Otonomi Daerah : Tinjaun Terhadap Dinamika Politik dan Pembangunan, Jakarta : Penerbit Mitra Wacana Media.

Timasheff, Nicholas. 1967. Social Change in The Twentieth Century, New York : Random House Pub.

Weber, Max. 2004. www.sage publication.com/ Weber Theory (diakses Mei 2004) 